\title{
The effect of estrogen on prolidase-dependent regulation of HIF-1 $\alpha$ expression in breast cancer cells
}

\author{
Arkadiusz Surazynski • Wojciech Miltyk • \\ Izabela Prokop · Jerzy Palka
}

Received: 30 October 2012/Accepted: 20 March 2013/Published online: 3 April 2013

(C) The Author(s) 2013. This article is published with open access at Springerlink.com

\begin{abstract}
The role of estrogen in breast cancer progression and activation of prolidase activity and HIF- $1 \alpha$ led us to study the effect of estrogen on nuclear HIF-1 $\alpha$ expression in breast cancer estrogen-dependent MCF-7 and estrogen-independent MDA-MB-231 cells. We have found that in MCF-7 cells (expressing $\alpha$ and $\beta$ estrogen receptor) cultured without estrogen receptor activator (phenol red, estradiol), HIF-1 $\alpha$ was down-regulated, compared to the cells cultured with estrogen receptor activator. This effect was not observed in MDA-MB-231 cells (expressing only $\beta$ estrogen receptor), suggesting that $\alpha$ estrogen receptor is involved in down-regulation of HIF-1 $\alpha$. However, in MDA-MB-231 cells (expressing high prolidase activity) cultured in the presence of prolidase substrates, Gly-Pro or Gly-HyPro, HIF- $1 \alpha$ expression was induced in a dosedependent manner, independently of estrogen receptor activation. In MCF-7 cells (with constitutively low prolidase activity) the effect of studied iminodipeptides on HIF- $1 \alpha$ expression was much less pronounced but it was estrogendependent, showing importance of prolidase activity in mechanism of this process. The data were supported by confocal microscopy bio-imaging of HIF- $1 \alpha$ in nucleus of MCF-7 and MDA-MB-231 cells that were cultured in the presence and absence of estrogen activator and prolidase substrates. It suggests that estrogen receptor may represent important therapeutic target in pharmacotherapy of estrogen receptor positive breast cancer, while ECM
\end{abstract}

\footnotetext{
A. Surazynski · I. Prokop · J. Palka $(\bowtie)$

Department of Medicinal Chemistry, Medical University of Bialystok, Kilińskiego 1, 15-089 Bialystok, Poland e-mail:pal@umb.edu.pl

W. Miltyk

Department of Pharmaceutical Analysis, Medical University of Bialystok, Kilińskiego 1, 15-089 Bialystok, Poland
}

degradation enzymes, including prolidase may represent target in pharmacotherapy of estrogen receptor negative breast cancers.

Keywords Estrogen - HIF-1 $\alpha \cdot$ MCF-7 .

MDA-MB-231 · Prolidase

\section{Introduction}

The role of estrogen in the promotion and development of breast cancer is well documented by epidemiological data and the therapeutic efficacy of anti-estrogen therapy [1]. More direct evidence was obtained with estrogen receptor (ER) positive breast cancer cell lines in which estrogens were found to stimulate the proliferation of these cells both in culture [2] and in nude mice [3]. However, ER positive tumor cells are poorly metastatic compared to ER negative ones [4] and more responsive to antiestrogens [5]. It may suggest a regulatory role of estrogens in breast cancer cell metastasis.

Estrogens are implicated in collagen metabolism and cell growth in several cell types [6-8]. Cell locomotion requires extensive degradation of extracellular matrix (ECM) components, including collagens [9]. Although extracellular metalloproteinases initiate the breakdown of collagen, the final step of its degradation is mediated by cytoplasmic prolidase.

Prolidase (E.C.3.4.13.9) is the enzyme that catalyzes the final step in ECM degradation by releasing proline or hydroxyproline from the carboxyl terminus of imidodipeptides [10]. Our previous study showed that prolidase participates not only in post-transcriptional regulation of collagen biosynthesis but also is involved in regulation at transcriptional level [11]. Several reports suggest that 
prolidase through regulation of expression of growth factors (e.g., vascular endothelial growth factor, VEGF; transforming growth factor $\beta$, TGF- $\beta$ ) and transcription factors (e.g., hypoxia inducible factor $1 \alpha$, HIF-1 $\alpha$ ) may play important role in wound healing, inflammation, and angiogenesis [11-14].

The most representative study demonstrated the role of products of prolidase activity, proline or hydroxyproline in regulation of HIF-1 $\alpha$ degradation. Over-expression of prolidase resulted in increased HIF-1 $\alpha$ levels and elevated expression of HIF-1 $\alpha$-dependent gene products, VEGF, and glucose transporter-1 (Glut-1). Mechanism for the accumulation of HIF- $1 \alpha$ was due to the inhibition of von Hippel-Lindau (VHL)-dependent degradation [11].

The current study was therefore undertaken to characterize the effect of estrogen on HIF-1 $\alpha$ expression in breast cancer estrogen-dependent MCF-7 and estrogen-independent MDA-MB-231 cell lines.

\section{Materials}

L-Glycyl-L-proline, L-proline, and Dulbecco's modified Eagle's medium with or without phenol red (DMEM) or controlled process serum replacement I, (CPSR1), sodium bicarbonate, penicillin, streptomycin, fetal bovine serum (FBS), Dulbecco's phosphate-buffered saline (DPBS), 5-bromo-4-chloro-3-indolyl phosphate/nitro blue tetrazolium liquid substrate reagent (BCIP/NBT), Monoclonal (mouse) anti- $\beta$-actin antibody, anti-Mouse IgG AP antibody, were purchased from Sigma Chemicals Co., USA, as were most other chemicals used. Nuclear extracts NE-PER kit was purchased from Pierce (Rockford, IL, USA). Monoclonal (mouse) anti-estrogen receptor $\alpha(\mathrm{ER} \alpha)$, was obtained from Santa Cruz Biotechnology, Inc., USA, monoclonal (mouse) anti-HIF-1 $\alpha$ (WB) was obtained from BD Transduction Laboratories, CA, USA, monoclonal (mouse) anti-Hypoxia Inducible Factor 1 Alpha (HIF-1alpha) (IF) StressMarq from Biosciences Inc. Canada, Goat Polyclonal anti-Mouse IgGheavy and light chain antibody conjugate Fluorescein Isothiocyanate (FITC), from Bethyl Laboratories, Inc. USA. Nitrocellulose membrane $(0.2 \mu \mathrm{m})$, sodium dodecylsulphate (SDS), polyacrylamide, molecular weight standards, and Coomassie Brilliant Blue R-250 were received from Bio-Rad Laboratories USA.

\section{Cell cultures}

The studies were performed on estrogen-dependent MCF-7 cells, expressing $\alpha$ and $\beta$ receptor and on estrogen-independent MDA-MB-231 cells, expressing only $\beta$ receptor. MCF-7 and MDA-MB-231 cells were maintained in
DMEM without phenol red supplemented with $10 \%$ CPSR1, $50 \mathrm{U} / \mathrm{ml}$ penicillin, $50 \mu \mathrm{g} / \mathrm{ml}$ streptomycin at $37{ }^{\circ} \mathrm{C}$ in a $5 \% \mathrm{CO}_{2}$ incubator. Cells were cultured in Costar flasks or in BD Falcon ${ }^{\mathrm{TM}}$ 96-well black/clear bottom tissue culture plates (optimized for imaging applications). For analysis, except bioimaging, sub-confluent cells were detached with $0.05 \%$ trypsin, $0.02 \%$ EDTA in calcium-free phosphate-buffered saline, counted in hemocytometer and plated at $5 \times 10^{5}$ cells per well of six-well plates (Nunc) in $2 \mathrm{ml}$ of growth medium. Cells reached about $80 \%$ of confluence at day 2 after plating and in most cases such cells were used for the assays.

Western blot analysis

Nuclear and cytoplasmic extracts were prepared by the standard protocol described in the NE-PER kit from Pierce, (Rockford, IL, USA). For Western blots, equal amounts of cell extract proteins (cytoplasmic or nuclear) were electrophoresed on SDS-PAGE. Slab SDS/PAGE was used, according to the method of Laemmli [15]. After SDSPAGE, the gels were allowed to equilibrate for $5 \mathrm{~min}$ in $25 \mathrm{mM}$ Tris, $0.2 \mathrm{M}$ glycine in $20 \%$ (v/v) methanol. The proteins were transferred to $0.2 \mu \mathrm{m}$ pore-sized nitrocellulose at $100 \mathrm{~mA}$ for $1 \mathrm{~h}$ by using a LKB 2117 Multiphor II electrophoresis unit. The nitrocellulose was incubated with: monoclonal anti-HIF- $1 \alpha$ and ER $\alpha$, at concentration $1: 1,000$ in $5 \%$ dried milk in Tris-buffered saline with Tween 20 (TBS-T) (20 mmol/1 Tris-HCl buffer, pH 7.4, containing $150 \mathrm{mmol} / \mathrm{l} \mathrm{NaCl}$ and $0.05 \%$ Tween 20) for $1 \mathrm{~h}$. In order to analyze HIF- $1 \alpha$ and ER $\alpha$ second antibodyalkaline phosphatase conjugated, anti-Mouse IgG (whole molecule) was added at concentration 1:5,000 in TBS-T and incubated for $30 \mathrm{~min}$ slowly shaking. Then nitrocellulose was washed with TBS-T $(5 \times 5 \mathrm{~min})$ and submitted to 5-bromo-4-chloro-3-indolyl phosphate/nitro blue tetrazolium liquid substrate reagent (BCIP/NBT).

\section{Prolidase activity}

The activity of prolidase was determined according to the method of Myara [10], which is based on colorimetric determination of proline using Chinard's reagent. Cells were scraped off and centrifuged at $200 \times g$ for $15 \mathrm{~min}$ and the supernatant was discarded. The cell pellet was suspended in $1 \mathrm{ml}$ of $50 \mathrm{mM}$ HEPES, $\mathrm{pH} 7.8$, and sonicated for $3 \times 10 \mathrm{~s}$ at $0{ }^{\circ} \mathrm{C}$. Samples were then centrifuged $(12,000 \times g, 30 \mathrm{~min})$ at $4{ }^{\circ} \mathrm{C}$ and the supernatant was used for protein determination (Bradford method). Activation of prolidase requires incubation with $\mathrm{Mn}(\mathrm{II}): 100 \mu \mathrm{l}$ of cell extract supernatant was mixed with $100 \mu \mathrm{l}$ of $50 \mathrm{mM}$ HEPES, pH 7.8 containing $\mathrm{MnCl}_{2}$ at a final concentration of $1 \mathrm{mM}$ in the mixture. After incubation for $24 \mathrm{~h}$ at $37{ }^{\circ} \mathrm{C}$, 
the prolidase reaction was initiated by adding $100 \mu \mathrm{l}$ of the activated mixture to $100 \mu \mathrm{l}$ of $94 \mathrm{mM}$ glycyl-proline (Gly-Pro) for a final concentration of $47 \mathrm{mM}$. After additional incubation for $1 \mathrm{~h}$ at $37^{\circ} \mathrm{C}$, the reaction was terminated with the addition of $1 \mathrm{ml}$ of $0.45 \mathrm{M}$ trichloroacetic acid. To parallel blank tubes, trichloroacetic acid was added at time "zero". Samples were centrifuged at $10,000 \times g$ for $15 \mathrm{~min}$. The released proline was determined by adding $0.5 \mathrm{ml}$ of the trichloroacetic acid supernatant to $2 \mathrm{ml}$ of a $1: 1$ mixture of glacial acetic acid: Chinard's reagent $(25 \mathrm{~g}$ of ninhydrin dissolved at $70{ }^{\circ} \mathrm{C}$ in $600 \mathrm{ml}$ of glacial acetic acid and $400 \mathrm{ml}$ of $6 \mathrm{M}$ orthophosphoric acid) and incubated for $10 \mathrm{~min}$ at $90^{\circ} \mathrm{C}$. The amount of proline released was determined colorimetrically by monitoring absorbance at $515 \mathrm{~nm}$ and calculated using proline standards. Enzyme activity was reported in nanomoles of proline released per minute per milligram of protein.

\section{Immunofluorescence}

Cells were cultured in BD Falcon ${ }^{\mathrm{TM}}$ 96-well black/clear bottom tissue culture plates optimized for imaging applications at 10,000 cells per well. After incubation, cells were rinsed with PBS and fixed with $3.7 \%$ formaldehyde solution at room temperature for $10 \mathrm{~min}$. After fixation, cells were washed three times with PBS and permeabilized with $0.1 \%$ Triton X-100 solution at room temperature for 5 min. Then, cells were washed twice with PBS, and nonspecific binding was blocked by addition of a $3 \%$ FBS solution and incubated at room temperature for $30 \mathrm{~min}$. After that time the cells were rinsed, incubated with antiHIF-1 $\alpha$ mouse monoclonal antibody for $1 \mathrm{~h}$ at room temperature, washed three times with PBS and incubated with fluorescent (FITC) anti-mouse secondary antibody for $60 \mathrm{~min}$ in the dark. After washing, nuclei were stained with Hoechst $33342(2 \mu \mathrm{g} / \mathrm{ml})$ and analyzed using confocal microscopy imaging.

\section{Confocal microscopy}

Cells were imaged with a BD Pathway 855 confocal system using a $20 \times(0.75 \mathrm{NA})$ objective. Cell populations were analyzed for cytoplasmic fluorescence intensity. Images of FITC-labeled cells were acquired using a 488/10 excitation laser and a 515LP emission laser.

\section{Statistical analysis}

In experiments the mean values for six assays \pm standard deviations (SD) were calculated. The results were analyzed using the ANOVA method, accepting $P<0.01$, as significant.

\section{Results}

The studies were performed on estrogen-dependent MCF-7 cells, expressing $\alpha$ and $\beta$ estrogen receptor and on estrogen-independent, MDA-MB-231 cells, expressing only $\beta$ estrogen receptor. In cultured cells, phenol red contained in medium mimics activity of estrogens [16]. In order to test the effect of estradiol on estrogen receptor $\alpha$ expression in MCF-7 and MDA-MB-231 cells, they were treated for $24 \mathrm{~h}$ with or without $1 \mathrm{nM}$ estradiol in medium with or without phenol red (PhR), containing $10 \%$ CPSR 1 . We found that in MCF-7 cell incubated without phenol red in medium, expression of estrogen receptor $\alpha$ (ER $\alpha$ ) was markedly reduced compared to cells cultured in medium with phenol red (Fig. 1a). An addition of $1 \mathrm{nM}$ estradiol to cells cultured in phenol red slightly up-regulated ER $\alpha$ expression while had no effect on the receptor expression in cells

A

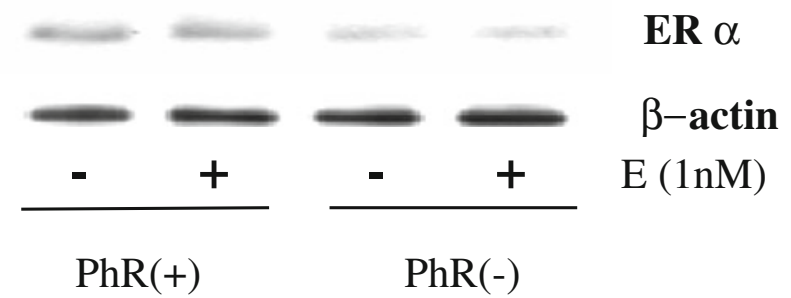

B
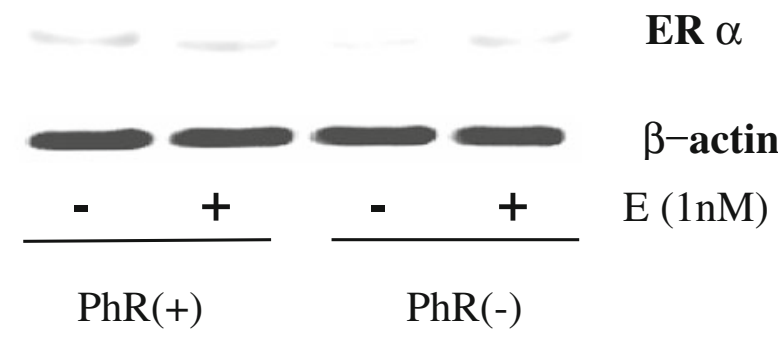

C

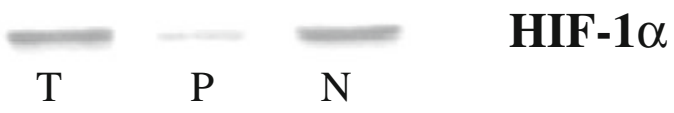

D

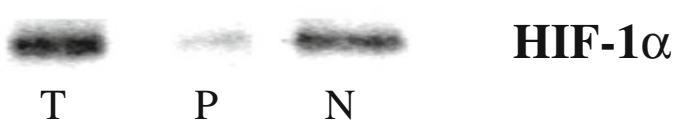

Fig. 1 Western blot for estrogen receptor $\alpha(E R \alpha)$ and $\beta$-actin in MCF-7 (a) and MDA-MB-231 (b) cells cultured in the absence (-) or presence $(+)$ of $1 \mathrm{nM}$ estrogen $(\mathrm{E})$ in DMEM with $(\mathrm{PhR}+)$ or without $(\mathrm{PhR}-)$ phenol red and $10 \%$ CPSR 1 for $24 \mathrm{~h}$. Western blot for HIF$1 \alpha$ in MCF-7 (c) and MDA-MB-231 (d) cells in total (T), cytoplasmic $(\mathrm{P})$, or nuclear $(\mathrm{N})$ extracts 
Fig. 2 Prolidase activity

(a) and expression of HIF-1 $\alpha$

(b) in MCF-7 and MDA-MB-

231 cells, cultured in DMEM with $\mathrm{PhR}(+)$, without $\mathrm{PhR}(-)$ or without $\mathrm{PhR}(-)$ phenol red in the presence of $1 \mathrm{nM}$ estrogen $(+\mathrm{E})$ and $10 \%$ CPSR 1 for $24 \mathrm{~h}$. Data shown represent mean $\pm \mathrm{SD}$ of 3 determinations and the difference is statistically significant by the ANOVA method $P<0.01$

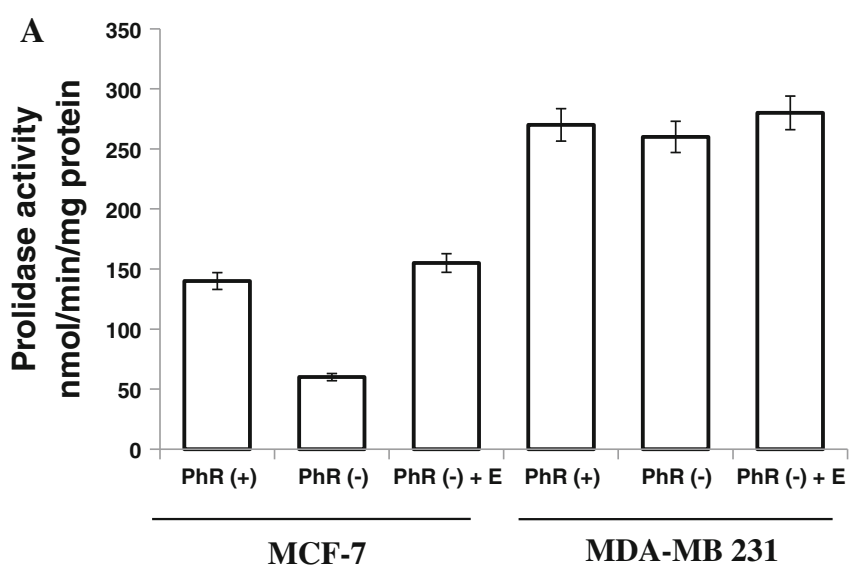

B

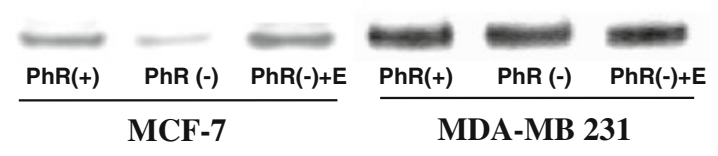

HIF-1 $\alpha$

MCF-7 cells cultured without estrogen, the increase in expression of HIF- $1 \alpha$ due to imidodipeptides is markedly lower then in the cells cultured in medium with estrogen (Fig. 3a). These results show that the effect of estrogen on the levels of HIF- $1 \alpha$ in nuclear extracts is related to prolidase function. The data are supported by confocal microscopy bio-imaging of HIF- $1 \alpha$ in nucleus of MCF-7 and MDA-MB-231 cells that were cultured in the presence and absence of estrogen activator and prolidase substrates (Fig. 4).

\section{Discussion}

Estrogens are known to stimulate the growth of normal and transformed epithelial cells [18]. The mechanism of their action involves interaction with estrogen receptor that after binding of ligand is targeted to the nucleus as an transcription factor [19]. However, activation of estrogen receptor is regulated not only by its ligands but also by number of factors, including kinases, phosphatases, and growth factors [20]. For instance, in endometrial cancer cells p38 mitogen-activated protein kinase (MAPK) signaling phosphorylates estrogen receptor $\alpha$, promoting its nuclear localization [21].

Despite the fact that estrogens play an important role in the promotion and development of female epithelialderived cancer [22], it has been postulated that estrogen receptor (ER) positive cancer cells are poorly metastatic compared to ER negative ones [4]. The mechanism of the regulatory role of estrogens in cancer cell growth and metastasis, however, is not understood. Although in this report we do not study growth and metastasis of breast cancer cells, the approach to understand the effect 
A

MCF-7 PhR (-)

\begin{tabular}{|c|c|c|c|c|}
\hline & & $=$ & 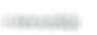 & HIF-1 $\alpha$ \\
\hline 0 & 1 & 5 & 10 & Gly-Pro (mM) \\
\hline & 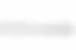 & $=$ & - & HIF-1 $\alpha$ \\
\hline 0 & 1 & 5 & 10 & Gly-HyPro (mM) \\
\hline
\end{tabular}

MCF-7 PhR (+)

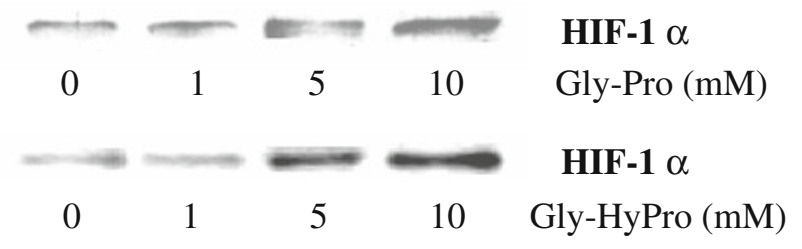

B

MDA-MB $231 \mathrm{PhR}(-)$

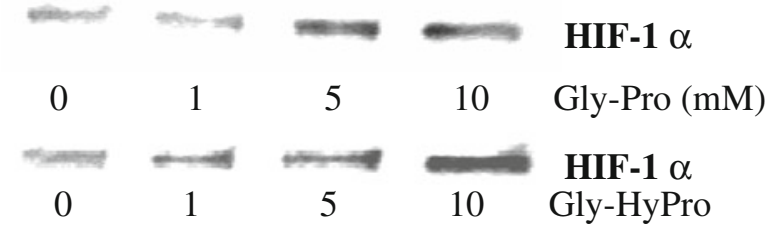

MDA-MB $231 \mathrm{PhR}(+)$

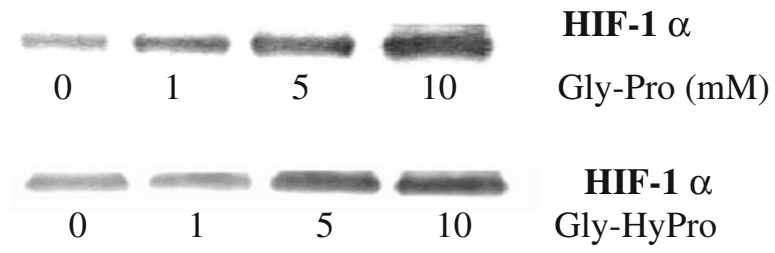

Fig. 3 Western blot analysis for HIF- $1 \alpha$ in MCF-7 (a) and MDAMB-231 (b) cells cultured in the absence (-) or presence $(+)$ of phenol red in DMEM with $10 \%$ CPSR 1 and submitted for $24 \mathrm{~h}$ to different concentrations of Gly-Pro or Gly-HyPro. Samples used for electrophoresis consisted of $20 \mu \mathrm{g}$ of protein of pooled cell extracts $(n=6)$

of estrogens on the processes is focused on the regulation of HIF-1 $\alpha$ expression.

It seems that in the context of breast cancer, the most important is contribution of prolidase to regulation of HIF- $1 \alpha$. The stability and activity of HIF- $1 \alpha$ are regulated by various post-translational modifications, hydroxylation, acetylation, and phosphorylation. Under normoxia, the HIF- $1 \alpha$ subunit is rapidly degraded via the von HippelLindau tumor suppressor gene product (pVHL)-mediated ubiquitin-proteasome pathway. The association of $\mathrm{pVHL}$ and HIF- $1 \alpha$ under normoxic conditions is triggered by the hydroxylation of prolines and the acetylation of lysine within a polypeptide segment known as the oxygendependent degradation (ODD) domain. On the contrary, in the hypoxia condition, HIF- $1 \alpha$ subunit becomes stable and interacts with coactivators such as p300/CBP to modulate its transcriptional activity. Overexpression of prolidase resulted in increased nuclear HIF-1 $\alpha$ levels and elevated expression of HIF-1-dependent gene products, vascular endothelial growth factor (VEGF), and glucose transporter1 (Glut-1). The activation of HIF- $1 \alpha$-dependent transcription was shown by prolidase-dependent activation of HREluciferase expression. In previous studies we used an oxygen-dependent degradation domain (ODD)-luciferase reporter construct as a surrogate for HIF- $1 \alpha$ in an in situ prolyl-hydroxylase assay. Since this reporter is degraded by VHL-dependent mechanisms, increased levels of HIF- $1 \alpha$ with prolidase expression were due to decreased hydroxylation. Additionally, the differential expression of prolidase in two breast cancer cell lines MCF-7 and MDAMB-231 showed prolidase-dependent differences in HIF- $1 \alpha$ levels [11]. These findings show that metabolism of imidodipeptides by prolidase plays a previously unrecognized role in angiogenic signaling, cell proliferation/ survival, and glucose metabolism.

In this study we have found that prolidase activity reflects nuclear localization of HIF- $1 \alpha$ in breast cancer cells. Furthermore, we have found that this phenomenon is due to estrogen receptor $\alpha$ subunit. The evidence was presented that up-regulation of prolidase activity by estrogen take place only in MCF-7 cells, expressing $\alpha$ estrogen receptor and not in MDA-MB-231 cells lacking this receptor. Therefore, we suggest that $\alpha$ estrogen receptor may be crucial for estrogen-dependent up-regulation of prolidase activity. Increase in prolidase activity in turn accelerate release of proline and hydroxyproline from iminodiopeotides, that inhibit degradation of HIF- $1 \alpha$, contributing to increase in nuclear localization of this transcription factor. In MCF-7 cells this mechanism contribute to activation of HIF- $1 \alpha$ function. However, in MDA-MB-231 cells with constitutively high prolidase activity, the HIF- $1 \alpha$ expression is independent of estrogen receptor activation. It seems that in MDA-MB-231 cells, HIF- $1 \alpha$ expression is regulated by final products of extracellular matrix (ECM) degradation, iminodipeptides, that are substrate for prolidase. The data presented in this study documented higher effectiveness of iminodipeptides in up-regulation of HIF- $1 \alpha$ in MDA-MB-231, than in MCF-7 cells. It suggests that ECM integrity is of critical importance for the maintenance of normal tissue. The linkage of ECM and hypoxia suggests that the metabolic system senses ECM degradation as a stress condition that requires neoangiogenesis. In fact, both HIF- $1 \alpha$ and prolidase are involved in angiogenesis. Patients with prolidase deficiency exhibit defective wound healing, 


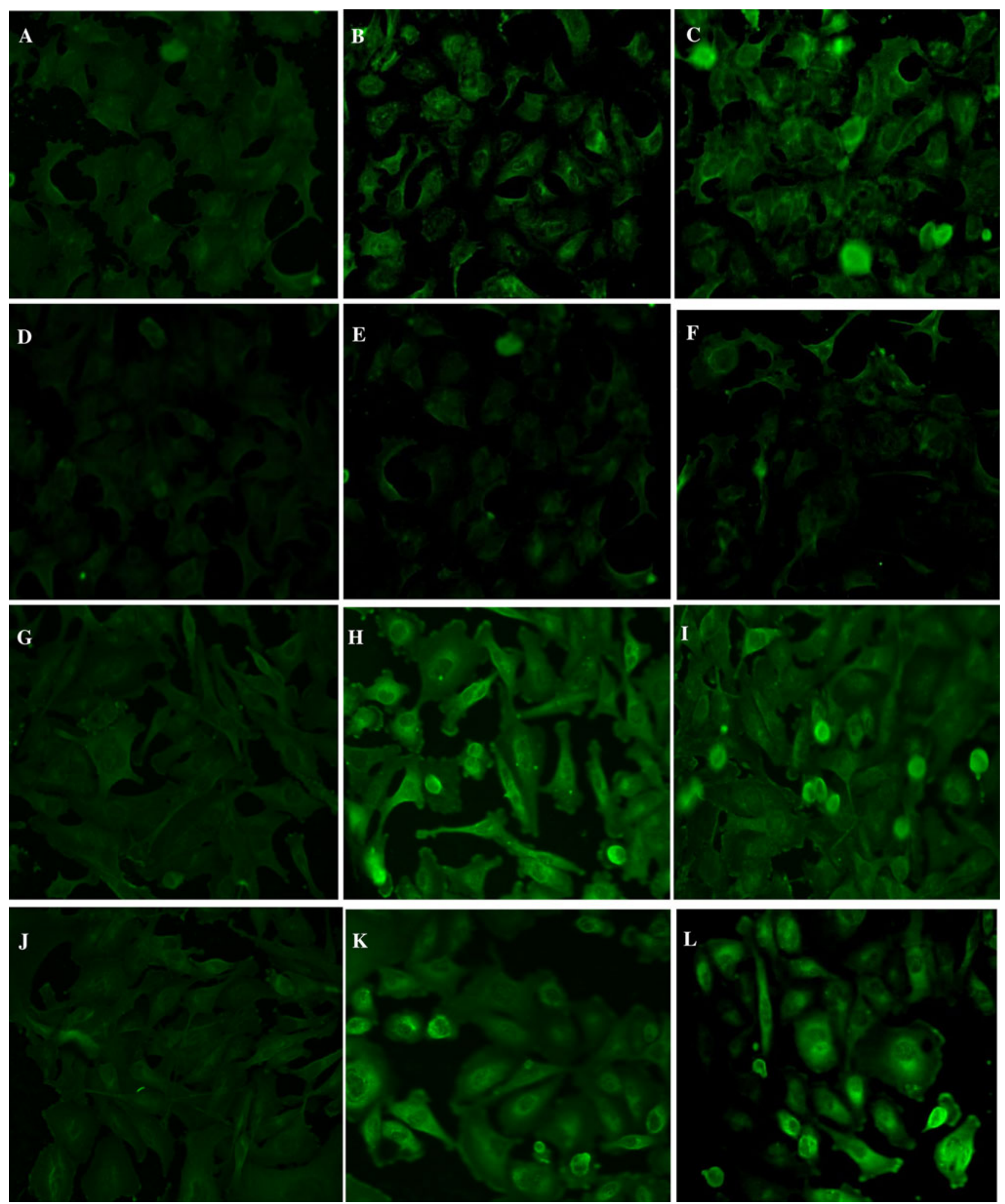

Fig. 4 Imaging analysis for HIF- $1 \alpha$ in MCF-7 cells cultured in the presence $(+)$ of phenol red in DMEM with $10 \%$ CPSR1 (a) and submitted for $24 \mathrm{~h}$ to $10 \mathrm{mM}$ concentration of Gly-Pro (b) or GlyHyPro (c) and MCF-7 cells cultured in the absence (-) of phenol red in DMEM with $10 \%$ CPSR1 (d) and submitted for $24 \mathrm{~h}$ to $10 \mathrm{mM}$ concentration of Gly-Pro (e) or Gly-HyPro (f). MDA-MB-231 cells cultured in the presence $(+)$ of phenol red in DMEM with $10 \%$ CPSR1 (g) and submitted for $24 \mathrm{~h}$ to $10 \mathrm{mM}$ concentration of GlyPro (h) or Gly-HyPro (i) and MDA-MB-231 cells cultured in the absence (-) of phenol red in DMEM with $10 \%$ CPSR1(j) and submitted for $24 \mathrm{~h}$ to $10 \mathrm{mM}$ concentration of Gly-Pro (k) or GlyHyPro (l) 
Scheme 1 .

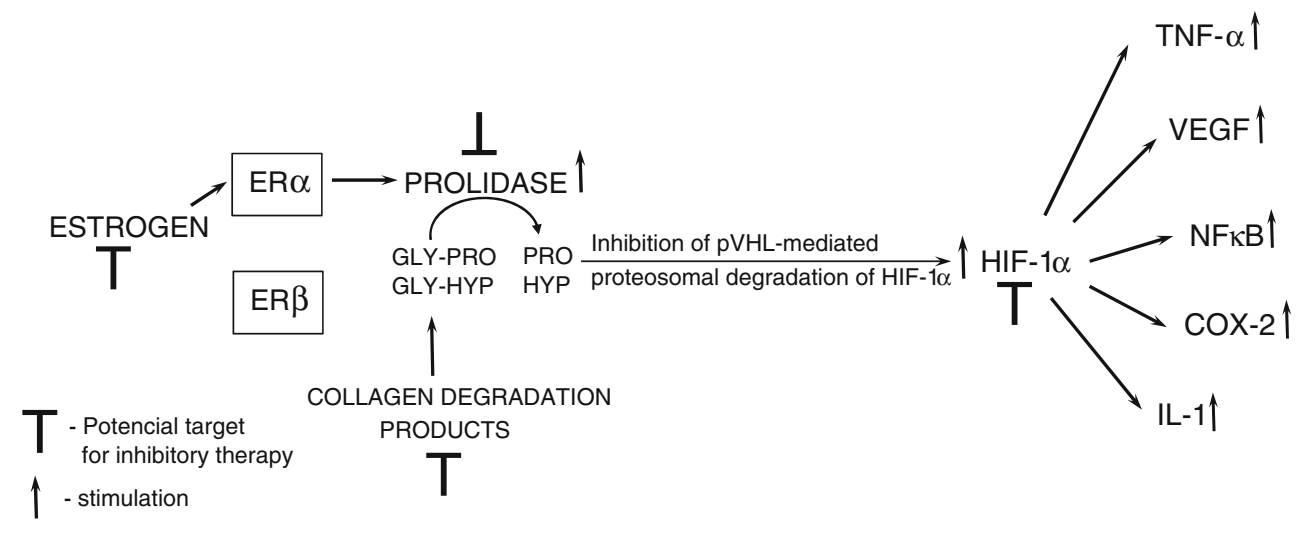

resulting in extensive skin ulcerations and immunodeficiency that contribute to frequent infections. Of special interest, histologic features on postmortem examination included marked angiopathy not only in skin ulcerations [23] but also in internal tissues [24], suggesting that the deficiency in prolidase may cause defective angiogenesis. Taking together the data suggest that estrogen receptor may represent important therapeutic target in pharmacotherapy of ER positive breast cancer, while ECM degradation enzymes, including prolidase may represent target in pharmacotherapy of ER negative breast cancers. The potential mechanism of this process is outlined in Scheme 1.

Acknowledgments This work was supported by Grants No. 3-14939 F from the Committee for Scientific Research.

Open Access This article is distributed under the terms of the Creative Commons Attribution License which permits any use, distribution, and reproduction in any medium, provided the original author(s) and the source are credited.

\section{References}

1. Jordan VC (1992) The strategic use of antiestrogens to control the development and growth of breast cancer. Cancer 15:977-982

2. Dickson RB, Lippman ME (1988) Control of human breast cancer by estrogen, growth factors, and oncogenes. Cancer Treat Res 40:119-165

3. Osborne CK, Hobbs K, Clark GM (1985) Effect of estrogens and antiestrogens on growth of human breast cancer cells in athymic nude mice. Cancer Res 45:584-590

4. Price JE, Polyzos A, Zhang RD, Daniel LM (1990) Tumorigenicity and metastasis of human breast carcinoma cell lines in nude mice. Cancer Res 50:717-721

5. Lerner LJ, Jordan VC (1990) Development of antiestrogens and their use in breast cancer: eighth cain memorial award lecture. Cancer Res 50:4177-4189

6. Baldekas JC, Gerstenfeld L, Sonenstein GE, Franzblau C (1982) Cell density and estradiol molulation of procollagen type III in cultured calf smooth muscle cells. J Cell Biol 257:12262-12265
7. Schmid MEC, Froesch ER (1988) Enhanced osteoblast proliferation and collagen gene expression by estradiol. Proc Natl Acad Sci USA 85:2307-2310

8. Surazynski A, Jarzabek K, Haczynski J, Laudanski P, Palka J, Wolczynski S (2003) Differential effects of estradiol and raloxifene on collagen biosynthesis in cultured human skin fibroblasts. Int J Mol Med 12:803-809

9. Liotta LA (1986) Tumor invasion and metastases-role of the extracellular matrix. Cancer Res 46:1-7

10. Myara I, Charpentier C, Lemonnier A (1982) Optimal conditions for prolidase assay by proline colorimetric determination: application to iminodipeptiduria. Clin Chim Acta 125:193-205

11. Surazynski A, Donald SP, Cooper SK, Whiteside MA, Salnikow K, Liu Y, Phang JM (2008) Extracellular matrix and HIF-1 signaling: the role of prolidase. Int J Cancer 122:1435-1440

12. Surazynski A, Miltyk W, Palka J, Phang JM (2008) Prolidasedependent regulation of collagen biosynthesis. Amino Acids 35:731-738

13. Surazynski A, Miltyk W, Prokop I, Palka J (2010) Prolidasedependent regulation of TGF $\beta$ and TGF $\beta$ receptor expressions in human skin fibroblasts. Eur J Pharmacol 649:115-119

14. Surazynski A, Liu Y, Miltyk W, Phang JM (2005) Nitric oxide regulates prolidase activity by serine/threonine phosphorylation. J Cell Biochem 96:1086-1094

15. Laemmli UK (1970) Cleavage of structural proteins during the assembly of the head of bacteriophage T4. Nature 227:680-685

16. Devleeschouwer N, Body JJ, Legros N, Muquardt C, Donnay I, Wouters P, Leclercq G (1992) Growth factor-like activity of phenol red preparations in the MCF-7 breast cancer cell line. Anticancer Res 12:789-794

17. Miltyk W, Anchim T, Wolczynski S, Palka J (1999) Estrogendependent regulation of prolidase activity in breast cancer MCF-7 cells. Gynecol Endocrinol 13:166-174

18. Key TJ, Pike MC (1988) The dose-effect relationship between "unopposed" oestrogens and endometrial mitotic rate: its central role in explaining and predicting endometrial cancer risk. Br J Cancer 57:205-212

19. Tsai MJ, O’Malley BW (1994) Molecular mechanism of action of steroid/thyroid receptor superfamily members. Annu Rev Biochem 63:451-486

20. Smith CL (1998) Cross-talk between peptide growth factor and estrogen signaling pathways. Biol Rep 58:627-632

21. Lee H, Bai W (2002) Regulation of estrogen receptor nuclear export by ligand-induced and p-38-mediated receptor phosphorylation. Mol Cell Biol 22:5835-5845

22. Jordan VC (1992) Overview from the International Conference on Long-Term Tamoxifen Therapy for Breast Cancer. J Natl Cancer Inst 84:231-234 
23. Arata J, Tada J, Yamada T, Oono T, Yasutomi H, Oka E (1991) Angiopathic pathogenesis of clinical manifestations in prolidase deficiency. Arch Dermatol 127:124-125
24. Sekiya M, Ohnishi Y, Kimura K (1985) An autopsy case of prolidase deficiency. Virchows Arch 496:125-131 